\title{
PELATIHAN BISNIS FASHION MELALUI WHATSAPP DALAM MENINGKATKAN PEMBERDAYAAN BAGI UMKM CIMAHI
}

\author{
Anisa Kusnaeni \\ IKIP Siliwangi, Cimahi, Jawa Barat, Indonesia \\ anisahalnista2@gmail.com
}

Received: Desember 2019 ; Accepted: Januari 2020

\begin{abstract}
This research is motivated by the fact that there is a social gap from the times that continues to develop resulting in reduced economic income because of the many competitors who continue to innovate and knowledge about the development of the use of technology and information in a society that is still less familiar. Therefore, the aim of this research is to create a fashion business training program through WhatsApp media in enhancing the empowerment of participants of the MSME fashion group acceleration in Cimahi City, in order to increase community income and the theoretical basis used in this study is the theory of the influence of social networks or WhatsApp on character education of students and community empowerment in the era of globalization. The research method used is descriptive qualitative with interview and observation techniques and the population of this study involved speakers or speakers in accordance with the field of experts (pashion), manager of the WhatsApp group of 1 person and 10 trainees. The author took 5 people who are simple. Research results from the training program which is still under the auspices of the government show that the UMKM fashion group accelerated participants can receive fashion business training well even though using whatshapp media processes are effective and efficient training.
\end{abstract}

Keywords: $\quad$ Social Networking, WhatsApp, Empowerment.

\begin{abstract}
ABSTRAK
Penelitian ini dilatarbelakangi oleh fakta adanya kesenjangan sosoial dari perkembangan zaman yang terus berkembang mengakibatkan pemasukan ekonomi berkurang karena banyaknya pesaing yang terus berinovasi dan pengetahuan tentang perkembangan kegunaan teknologi dan informasi di lingkungan masyarakat yang masih kurang familiar. Maka dari itu, Tujuan peneliti ini adalah untuk membuat program pelatihan bisnis fashion melalui media WhatsApp dalam meningkatkan pemberdayaan bagi peserta akselerasi kelompok fashion UMKM di Kota Cimahi, guna meningkatkan pendapatan masyarakat dan landasan teori yang digunakan dalam penelitian ini adalah teori pengaruh jejaring sosial atau WhatsApp terhadap pendidikan karakter peserta didik dan pemberdayaan masyarakat di era globalisasi. Metode penelitian yang digunakan adalah kualitatif deskriftif dengan teknik wawancara dan observasi serta Populasi penelitian ini melibatkan narasumber atau pemateri yang sesuai dengan bidang ahlinya (pashion), pengelola group WhatsApp 1 orang dan 10 orang peserta pelatihan. Penulis mengambil 5 orang sempel. Hasil penelitian dari program pelatihan yang masih dibawah naungan pemerintah menunjukan peserta akselerasi kelompok fashion UMKM dapat menerima pelatihan bisnis fashion dengan baik walaupun menggunakan media whatshapp peroses pelatihanya berjalan dengan efektif dan efisien.Sehingga meningkatnya kualitas hidup dan dapat meningkatnya pendapatan serta kesejahteraan ekonomi di cimahi semakin meningkat.
\end{abstract}

Kata Kunci: Jejaring sosial ,WhatsApp, Pemberdayaan. 
How to Cite: Kusnaeni, A. (2020). Pelatihan Bisnis Fashion Melalui Whatsapp Dalam Meningkatkan Pemberdayaan Bagi Umkm Cimahi. Comm-Edu (Community Education Journal) 3 (1), 42-49.

\section{PENDAHULUAN}

Seiring dengan perkembangan zaman, kebutuhan manusia akan informasi dan teknologi semakin berkembang pesat. Salah satu teknologi yang memungkinkan setiap orang dapat mengakses informasi dalam kehidupan sehari-hari adalah internet. Dengan menggunakan internet, masyarakat dari berbagai kalangan usia, gender, kelas sosial, ekonomi dan budaya dapat mengetahui berbagai perkembangan yang terjadi di lingkungan sekitar mereka serta dapat berinteraksi satu sama lain tanpa dibatasi oleh ruang dan waktu. Jejaring sosial merupakan situs dimana seseorang dapat membuat web page pribadi dan terhubung dengan setiap orang yang bergabung dalam jejaring sosial yang sama untuk berbagi informasi dan berkomunikasi (Zubaedi 2013 dalam Koni, 2016, hal. 38).

Jejaring sosial diartikan sebagai sebuah sistem struktur sosial yang terdiri dari elemen-elemen individu atau organisasi. Jejaring sosial merupakan sebuah struktur sosial atau tatanan sosial dimana individu ataupun organisasi yang terlibat di dalamnya memiliki hubungan yang spesifik. Maka dari itu dengan adanya jejaring sosial kita bisa memanfaatkan sebagai media pembelajaran atau media untuk menyampaikan sebuah materi dan ilmu pengetahuan. Saat ini, whatsapp telah menjadi salah satu kategori jejaring sosial yang marak digunakan oleh sebagian besar masyarakat di Indonesia, keunggulanya seperti mengirimkan gambar, suara, video, mengirim file - file atau berkas yang penting sampai dengan bisa digunakan untuk menelpon atau video coll. WhatsApp juga bisa membuat group dari kontak yang sudah terdaftar di aplikasi whatsApp, maka dari sini kita bisa melihat dimana hubungan sosial dan saling ketergantungan antar negara serta hubungan antara manusia menjadi semkin tidak terbatas. Whatsapp banyak diminati oleh sebagian masyarakat Indonesia khususnya ibu-ibu atau bapak- bapak yang memiliki usaha atau usaha kecil menengah (UKM). Mengingat masalah yang sudah terjadi di masa lalu, Krisis ekonomi tahun 1997-1998 merupakan kejadian paling suram dalam sejarah perekonomian di Indosesia, sehingga banyaknya pemberentian kerja (PHK) Diberbagai Perusahaan. Namun disisi lain usaha kecil menengah (UKM) tetap bertahan, bahkan ada yang memaparkan bahwa usaha kecil menengah (UKM), merupakan penopang perekonomian nasional masyarakat kecil dan menengah.

Berdasarkan data Kementrian Koprasi Usaha Kecil Menengah, di Indonesia sektor Usaha Kecil, Menengah menarik 91,8 juta tenaga kerja dari 113,83 juta angkatan kerja. UKM juga mampu memiliki kontribusi besar terhadap Pendapatan Domestik Bruto (PDB) sehingga 55,6 $\%$ atau Rp. 2.6094 terliun. Kontribusi UKM bagi jawa barat pun tidak kalah tinggi, dimana sebanyak 8,21 juta unit UKM di jabar sanggup menyerap 13,79 juta orang atau 88,5\% total tenaga kerja dijawa barat. Badan pusat statistika (BPS) di kota cimahi Jumlah Perusahaan industri pada tahun 2012 di wilayah Cimahi Selatan industri kecil 348 perusahaan, sedang 75, besar 48, sedangkan Cimahi Tengah 104, Sedang 16, Besar 16 dan wilayah Cimahi Utara perusahaan kecil 48, sedang 14, besar 1 .

Berdasarkan uraian diatas masih banyak UKM yang blum terdata dan blum adanya surat perijinan atau Legalitas usaha. Tetapi Usaha Mikro, Kecil dan Menengah (UMKM) telah berkontribusi yang sangat besar dalam membantu perekonomian Indonesia sehingga dalam kenyataanya terbukti dapat meningkatkan Produk Domestik Bruto (PDB). 
Walaupun UMKM banyak berkontribusi tetapi permasalahan sosial akibat perkembangan zaman yang terus berkembang mengakibatkan pemasukan ekonomi berkurang diakibatkan banyaknya pesaing yang terus berinovasi dan kurangnya pengetauan tentang perkembangan teknologi dan informasi di lingkungan masyarakat serta kurang percaya diri dan motivasi berwirausaha menurun akibat perkembangan zaman. Maka dari itu penggunaan whatsApp adalah salah satu metode sebagai prantara untuk pengembangan kualitas sumber daya manusia (SDM) bagi UMKM yang ada di Kota Cimahi.

Pengembangan kualitas Sumber Daya Manusia (SDM) merupakan hal yang mendasar disamping sumber daya alam serta sumber daya ilmu pengetahuan dan teknologi. Pendidikan merupakan salah satu aspek yang memiliki peranan penting bagi pengembangan sumber daya manusia tersebut, sehingga pembangunan dapat berjalan dengan baik. Salah satu bentuk pendidikan yang dapat menunjang pengembangan sumber daya manusia tersebut adalah melalui Pendidikan luar sekolah.

Menurut Ardiwinata dan Mulyono (2018) menjelaskan tentang tugas pendidikan luar mengantisipasi sekolah yaitu : membelajarkan warga belajar agar mereka memiliki dan mengembangkan keterampilan, pengetahuan, sikap, nilai-nilai dan aspirasi untuk pemungkinan perubahan di masa depan, dan membelajarkan warga belajar agar mereka mampu meningkatkan dan memanfaatkan sumberdaya alam guna meningkatkan taraf hidupnya.

Program pemberdayaan adalah pendidikan yang dapat memberikan bekal keterampilan yang praktis, terpakai, terkait dengan kebutuhan pasar kerja, peluangusaha dan potensi ekonomi atau industri yang ada di masyarakat (Saepudin \& Mulyono, 2019).

Berdasarkan uraian di atas, maka dalam kegiatan pemberdayaan masyarakat kali ini, pelaksana ingin mensosialisasikan pelatihan tentang bisnis fashion melalui whatsapp materi yang akan diberikan yaitu sebagai berikut : 1) Trend Fashion, 2) Teknik Marketing, 3) Legalitas Usaha dan Pembuatan Dokumen Bisnis untuk Mitra, 4) Digital Marketing 5) Poto Produk Mengunakan alat Sederhana, 6) Penguatan Logo Brand, DLL.

Dari matrei di atas, pelaksana ingin peserta yang di berdayakan menjadi lebih mandiri dan lebih kuat untuk bersaing di dunia luar karena sudah di berikan pembekalan yang di berikan dari program pelatihan bisnis fashion melalui media whatsapp dalam meningkatkan pemberdayaan bagi peserta akselerasi kelompok fashion UMKM di Kota Cimahi.

\section{LANDASAN TEORI}

\section{Jejaring Sosial melalui WhatsApp}

Jejaring sosial diartikan sebagai sebuah sistem struktur sosial yang terdiri dari elemen-elemen individu atau organisasi. Jejaring sosial merupakan sebuah struktur sosial atau tatanan sosial dimana individu ataupun organisasi yang terlibat di dalamnya memiliki hubungan yang spesifik. Jejaring sosial merupakan situs dimana seseorang dapat membuat web page pribadi dan terhubung dengan setiap orang yang bergabung dalam jejaring sosial yang sama untuk berbagi informasi dan berkomunikasi Zubaedi (2013, dalam Koni, 2016, hal. 38)

Maka dari itu dengan adanya jejaring sosial kita bisa memanfaatkan sebagai media pembelajaran atau media untuk menyampaikan sebuah materi dan ilmu pengetahuan. Saat ini, whatsapp telah menjadi salah satu kategori jejaring sosial yang marak digunakan oleh 
sebagian besar masyarakat di Indonesia, keunggulanya seperti mengirimkan gambar, suara, video, mengirim file - file atau berkas yang penting sampai dengan bisa digunakan untuk menelpon atau video coll. proses pembelajaran dapat dilakukan secara mandiri dengan cara memanfaatkan berbagai media pembelajara salah satunya penggunaan whatsapp melalui grup whatsapp.

Menurut Hamijoyo dalam Kamil (2010: 32) lebih jauh memberikan definisi pendidikan luar sekolah adalah Suatu pendidikan yang terorganisir secara sistematis dan kontinyu diluar sisitem persekolahan mealui proses hubungan sosoial membimbing individu kelompok dan massyarakat suapaya memiliki sifat dan cita-cita sosial yang positif dan konstruktif guna meningkatkan hidup dibidang material, sosial dan mental dalam rangka usaha mewujudkan kesejahteraan sosial, kecerdasan bangsa dan persahabatan antar manusia.

\section{Pemberdayaan Masyarakat}

Menurut Mulyana dalam Rakhman (2015) menyebutkan bahwasannya pemberdayaan adalah upaya memampukan (enabling) masyarakat kecil atau bawahan yang selama ini dianggap tidak atau kurang berperan agar meningkat dan memiliki kemampuan yang lebih baik sehubungan dengan status dan peranan mereka di dalam sistem sosial. Pemberdayaan tidak hanya sekedar menghasilkan nilai tambah tetapi nilai manfaat yang berorientasi kebutuhan masyarakat.

Menurut Edi Suharto (2005 dalam Koswara (2014: 46) Pemberdayaan adalah sebuah proses sebagaimana orang menjadi cukup kuat untuk berpartisifasi, dalam berbagai pengontrol dan mempengaruhi terhadap kejadian-kejadian serta lembaga-lembaga yang mempengaruhi kehidupannya. Dalam Pemberdayaan menekankan bahwa orang memperoleh keterampilan, pengetahuan, dan kekuasaan yang cukup untuk mempengaruhi kehidupannya dan kehidupan orang lain yang menjadi perhatian.

\section{Usaha Mikro dan Menengah (UMKM) Cimahi}

Usaha mikro atau usaha kecil merupakan kekuatan ekonomi kerakyatan yang tangguh. Hal ini telah terbukti ketika terjadi krsis ekonomi tahun1998, usaha kecil mampu tetap eksis dari terpaan krisis ekonomi yang melanda indonesia dan dunia. Begitupun realitasnya usaha menengah ke atas (usaha makro) hanya dikuasai oleh segelintir orang saja. sebaliknya usaha kecil dimiliki oleh banyak masyarkat dengan berbagai jenis usaha baik yang ada di perkotaan maupun di pedesaan. Usaha mikro juga melibatkan banyak tenagga kerja, karena usaha dan proses produksi ini dilakukan hampir sepenuhnya dengan manual .

Ekonomi rakyat dipahami sebagai kegiatan ekonomi yang melibatkan banyak orang. Ekonomi rakyat ini menurut Kartasasmita dalam Anwas (2014) merupakan ekonomi masyarakat lapisan bawah yang bersifat tradisional, skala usaha kecil, dan bersifat sekedar bertahan untuk mempertahankan hidup. Badan pusat statistika (BPS) di kota cimahi Jumlah Perusahaan industri pada tahun 2012 di wilayah Cimahi Selatan industri kecil 348 perusahaan, sedang 75, besar 48, sedangkan Cimahi Tengah 104, Sedang 16, Besar 16 dan wilayah Cimahi Utara perusahaan kecil 48, sedang 14, besar 1.

Maka dari itu pemerintah membuat Program pemberdayaan untuk kelompok fashion bagi UMKM kota cimahi. pelatihan ini yang masih di naungi oleh pemerintah dan mengikut sertakan lembaga - lembaga yang terkait guna menyukseskan atau mempelancar program pelatihan tersebut. Dengan adanya pelatihan ini melibatkan narasumber atau pemateri yang 
46 Kusnaeni, A, Pelatihan Bisnis Fashion Melalui WhatsApp dalam Meningkatkan Pemberdayaan bagi UMKM Cimahi

sesuai dengan bidang ahlinya (passion), pengelola group whatsapp 1 orang dan 10 orang peserta pelatihan.

\section{METODE PENELITIAN}

Metode penelitian menggunakan metode deskriptif dengan pendekatan kualitatif yaitu sebuah metode penelitian yang berusaha menggambarkan objek sesuai dengan dan apa adanya. Penelitian deskriptif disebut juga penelitian non eksperimen. Karena dalam penelitian tidak ada manipulasi variabel dan juga tidak melakukan kontrol setingan terhadap variabel penenlitian. Menurut Creswell dalam Darmadi (2014: 287) menyebutka bahwa pendekatan kualitatif adalah suatu proses penelitian pemahaman yang berdasarkan pada metodologi yang menyelidiki suatu fenomena sosial dan masalah manusia.

Teknik pengumpulan data melalui wawancara, observasi dan penelitian ini dilakukan ke pada peserta akselerasi kelompok fashion UMKM Di Kota Cimahi. Populasi merupakan penggeneralisasian berupa subjek/ objek yang di teliti untuk dipelajari dan kemudian di ambil kesimpulannya. Populasi penelitian ini melibatkan narasumber pemateri yang sesuai dengan bidang ahlinya (passion), pengelola group WhatsApp 1 orang dan 10 orang peserta pelatihan. Sedangkan sempel adalah sebagian dari populasi yang di jadikan sebagai objek/ subjek peneliti dan untuk menentukan sempelnya, penulis mengambil 5 orang. Tujuan pengambilan sampel ini untuk memudahkan dan mempercepat penelitian dalam mendapatkan informasi yang cukup dikarenakan keterbatasan waktu, tenaga, dan biaya yang dibutuhkan, agar dapat ditangani lebih teliti. Menurut Sugiyono (2014: 145) dalam observasi ini, peneliti terlibat dengan kegiatan sehari-hari yang sedang diamati atau yang digunakan sebagai sumber data penelitian.

\section{HASIL DAN PEMBAHASAN}

\section{HASIL}

Berdasarkan penelitian yang dilakukan, ditemukan hasil sebagai berikut :

Pertama, proses pelatihan bisnis fashion melalui whatsapp dalam meningkatkan pemberdayaan bagi peserta akselerasi kelompok fashion Di Kota Cimahi. Berdasarkan Proses awal pelatihan Responden saat menanggapi pelatihan ini sangat antusias mengikuti pelatihan dan saat menjelaskan atuaran serta tata cara penggunaan yang ada di group whatsapp sampai di pemberian materi pelatihan, peserta akselerasi sangatlah komperatif dan aktif bertanya.

Kedua, dampak dari pelatihan bisnis fashion melalui whatsapp. Berdasarkan penelitian ini yaitu, motivasi peserta dalam mencari ilmu tentang dunia bisnis feshion lebih semangat dan selalu aus dalam bidang pengetahuan, peserta lebih percaya diri dalam mempromosikan barang jualnya dan manajemen usaha peserta lebih rapih dan tersusun serta lebih banyak menjalin kemitran - kemitraan dengan lembaga atau yayasan yang berkaitan dengan usahanya.

Ketiga, Hasil pemberdayaan melalui pelatihan menggunakan media whatsApp dapat disimpulkan bahwa taggapan responden menunjukan hampir semua responden menjawab yang sama, berdasarkan kemampuan terhadap penguasaan materi bisnis fashion tidak mendapat kesulitan, karena hampir semuanya sudah mempunyai kemampuan dasar di bidang fashion dan faktor pendukung dalam pelatihan bisnis fashion melalui whatsapp yaitu program di atur oleh pengelola langsung dan pemerintah menjalin kerja sama dengan lembaga - 
lembaga terkait jadi proses pelatihan saat memberikan materi sangatlah membantu mempelancar proses pembelajaran karena materi yang di berikan relefan sesuai dengan ahli bidangnya. Dengan demikian pemberdayaan melalui pelatihan menggunakan media whatsApp dapat diterima dengan baik dan peroses pelatihanya berjalan dengan efektif dan efisien serta pelaku usaha memberitahu bahwa usaha yang ia miliki menjadi banyak pemesanan dan konsumen pemesanan lebih banyak dari sebelumnya.

\section{PEMBAHASAN}

Sesuai dengan hasil diatas maka peneliti melakukan pembinaan ke pada peserta akselerasi kelompok fashion UMKM Kota Cimahi berupa pemberian pelatihan untuk memberdayakan masyarakat yang mempunyai pelaku usaha khususnya di bidang fashion untuk menunjang kemandirian masyarakat dan meningkatkan perekonomian masyarakat UMKM Di Kota Cimahi.

Pertama, mengenai bagaimana proses pelatihan bisnis fashion melalui WhatsApp dalam meningkatkan pemberdayaan bagi peserta akselerasi kelompok fashion Di Kota Cimahi. Berdasarkan Proses awal pelatihan Responden saat menanggapi pelatihan ini sangat antusias mengikuti pelatihan dan saat menjelaskan atuaran serta tata cara penggunaan yang ada di grup WhatsApp sampai di pemberian materi pelatihan, peserta akselerasi sangatlah komperatif dan aktif bertanya menurut Abdurrokhman Ginting dalam Koswara (2014: 43) pelatihan adalah suatu proses belajar untuk menguasai keterampilan , pengetahuan dan sikap yang baru untuk mempersiapkan seseorang agar mampu melakukan pekerjaan yang saat ini menjadi tanggungjawabnya atau yang akan menjadi tanggungjawabnya kelak sebagai bagian dari perkembangan individu maupun organisasi dimana ia bekerja.

Kedua, mengenai dampak apa saja yang ditimbulkan dari pelatihan bisnis fashion dalam meningkatkan pemberdayaan UMKM Di kota Cimahi, yaitu motivasi peserta dalam mencari ilmu tentang dunia bisnis feshion lebih semangat dan selalu aus dalam bidang pengetahuan, peserta lebih percaya diri dalam mempromosikan barang jualnya dan manajemen usaha peserta lebih rapih dan tersusun serta lebih banyak menjalin kemitran - kemitraan dengan lembaga atau yayasan yang berkaitan dengan usahanya dilihat dari hasil penelitian peserta akselerasi kelompok fashion yang sudah diberdayakan melalui pelatihan banyak sekali perkembangan dan cukup untuk berdiri sendiri agar bisa mengasah pengetahuan pengetahuan yang sudah di dapat dari pelatihan tersebut. Menurut Mulyana dalam Rakhman (2015) menyebutkan bahwasannya pemberdayaan adalah upaya memampukan (enabling) masyarakat kecil atau bawahan yang selama ini dianggap tidak atau kurang berperan agar meningkat dan memiliki kemampuan yang lebih baik sehubungan dengan status dan peranan mereka di dalam sistem sosial. Pemberdayaan tidak hanya sekedar menghasilkan nilai tambah tetapi nilai manfaat yang berorientasi kebutuhan masyarakat.

Ketiga, mengenai hasil pemberdayaan melalui pelatihan dapat disimpulkan bahwa taggapan responden menunjukan hampir semua responden menjawab yang sama, berdasarkan kemampuan terhadap penguasaan materi bisnis fashion tidak mendapat kesulitan, karena hampir semuanya sudah mempunyai kemampuan dasar di bidang fashion dan faktor pendukung dalam pelatihan bisnis fashion melalui WhatsApp yaitu program di atur oleh pengelola langsung dan pemerintah menjalin kerja sama dengan lembaga - lembaga terkait jadi proses pelatihan saat memberikan materi sangatlah membantu mempelancar proses pembelajaran karena materi yang di berikan relefan sesuai dengan ahli bidangnya. Dengan demikian pemberdayaan melalui pelatihan menggunakan media whatsApp dapat diterima 
dengan baik dan peroses pelatihanya berjalan dengan efektif dan efisien serta pelaku usaha memberitahu bahwa usaha yang ia miliki menjadi $b$ anyak pemesanan dan konsumen pemesanan lebih banyak dari sebelumnya. Menurut Edi Suharto (2005 dalam Koswara, 2014: 46) Pemberdayaan adalah sebuah proses sebagaimana orang menjadi cukup kuat untuk berpartisifasi, dalam berbagai pengontrol dan mempengaruhi terhadap kejadian-kejadian serta lembaga-lembaga yang mempengaruhi kehidupannya. Dalam Pemberdayaan menekankan bahwa orang memperoleh keterampilan, pengetahuan, dan kekuasaan yang cukup untuk mempengaruhi kehidupannya dan kehidupan orang lain yang menjadi perhatian.

\section{KESIMPULAN}

Pertama, mengenai bagaimana proses pelatihan bisnis fashion melalui whatsapp dalam meningkatkan pemberdayaan bagi peserta akselerasi kelompok fashion dapat disimpulkan bahwa proses pelatihan dapat berjalan dengan lacar karna adanya partisipasi dari peserta itu sendiri dan proses pelatihan mempersiapkan seseorang agar mampu melakukan pekerjaan yang saat ini menjadi tanggungjawabnya atau yang akan menjadi tanggungjawabnya kelak sebagai bagian dari perkembangan individu itu sendiri.

Kedua, mengenai dampak yang ditimbulkan dari pelatihan bisnis fashion dalam meningkatkan pemberdayaan UMKM Di kota Cimahi, yaitu dapat disimpulkan bahwa upaya yang dilakukan pemerintah melalui pemberdayaan cukup berdampak begitu banyak karena proses pemberdayaan adalah upaya memampukan masyarakat kecil yang selama ini dianggap tidak mampu berperan agar meningkat dan memiliki kemampuan yang lebih baik sehubungan dengan status dan peranan mereka di dalam sistem sosial dan menghasilkan nilai yang bermanfaat berorientasi dari kebutuhan masyarakat itu sendiri.

Ketiga, mengenai hasil pemberdayaan melalui pelatihan dapat disimpulkan bahwa proses pemberdayaan dalam program pelatihan melalui whatsApp berjalan dengan efektif dan efisien. Dari sini kita bisa liat proses sebagaimana orang menjadi cukup kuat untuk berpartisifasi, dalam berbagai pengontrol dan mempengaruhi terhadap kejadian-kejadian atau pengeruh dari lembaga-lembaga yang mempengaruhi kehidupannya maka dalam Pemberdayaan menekankan bahwa orang memperoleh keterampilan, pengetahuan, dan kekuasaan yang cukup untuk mempengaruhi kehidupannya dan kehidupan orang lain yang menjadi perhatian.

\section{DAFTAR PUSTAKA}

Anwas, O. M. (2014). Pemberdayaan Masyarakat Di Era Globalisasi. Bandung: Alfabeta.

Ardiwinata, J. S., \& Mulyono, D. (2018). Community Education in the development of The Community. EMPOWERMENT: Jurnal Ilmiah Program Studi Pendidikan Luar Sekolah, 7(1), 25-35.

Darmadi, H. (2014). Metode Penelitian Pendidikan dan Sosial Teori Konsep dan Implementasi. Bandung: Alfabeta.

Kamil, M. (2010). Model Pendidikan dan Pelatihan (Konsep dan Aplikasi). Bandung: Alfabeta. 
Koni, S. M. (2016). Pengaruh Jejaring Sosial Terhadap Pendidikan Karakter Peserta Didik. Manajemen Pendidikan Islam vol 4, no 2, 38.

Koswara, R. (2014). Manajemen Pelatihan Life Skill Dalam Upaya Pemberdayaan Santri Di Pondok Pesantren. Empowerment Vol. 4 Nol.

Rakhman, A. (2015). Efektifitas Pemberdayaan Terhadap anggota Persatuan Istri Prajurit (Persit). Empowerment, Vol 4 No. 2.

Saepudin, A., \& Mulyono, D. (2019). Community education in community development. EMPOWERMENT: Jurnal Ilmiah Program Studi Pendidikan Luar Sekolah, 8(1), 65-73.

Sugiyono. (2014). Metode Penelitian Kuantitatif dan R\&D . Bandung: Alfabeta. 